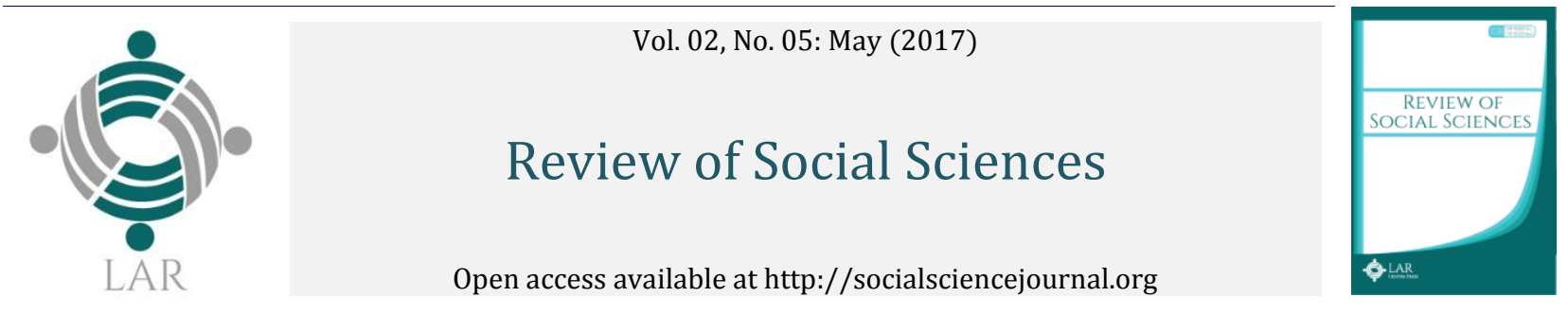

\title{
Ethno-Religious Pluralism and Sustainable National Development: The Nigeria Experience
}

\author{
Ntamu, G.U. a, Eneji, Chris-Valentine Ogar ${ }^{b *}$, Asor, Love Joseph c, Ochiche, C. ${ }^{\mathrm{d}}$ \\ ${ }^{a}$ Dept. of Religious and Cultural Studies, University of Calabar, Nigeria. \\ b Rural Development, Dept. of Geography, Modibbo Adama University of Technology, Yola, Nigeria. \\ c Dept. of Continuing Education and Development studies, University of Calanbar, Nigeria. \\ d Rural Development, Dept. of Geography and Environmental Science, University of Calabar, Nigeria. \\ *Corresponding author's email address: vcogareneji@gmail.com, vcogareneji@unical.edu.ng
}

\section{A R T I C LE IN F O}

Received: 21-01-2017

Accepted: $15-02-2017$

Available online: 19-05-2017

\section{Keywords:}

Destruction of lives and

properties;

Ethnicity;

Ethnocentrism;

Religious intolerance;

Religious pluralism;

sustainable national development

JEL Classification:

Q01,Q56

\begin{abstract}
A B S T R A C T
Ethno-religious pluralism and sustainable national development in Nigeria seem a paradox as well as an unattainable goal. Lives and properties have been recklessly destroyed with unabated zeal without giving consideration to our national diversities. This study was carried out in sixteen Nigerian Universities with a sample was made up of 800 lecturers divided into north and south. The sampling technique adopted was the multi-staged random sampling technique; data was generated through the use of a structured questionnaire administered directly by the researchers and ten research assistants over a period of 3 months. The researchers formulated two research questions and two hypotheses to guide the study. Data generated from the field using the instrument was coded and analyzed using the independent t-test analysis. Results obtained showed that Muslim staff religious tolerance (15.9>8.2); this produced tvalue of 33.9 with a p-value higher than the .05 significance level with 798 degrees of freedom, this implies that religious tolerance does significantly influence sustainable national development. The result of the second hypothesis also shows that mean score for the North is slightly greater than the mean score for the South $(11.86>10.73)$; this produced t-value of 2.41 with a p-value higher than the .05 significance level with 798 degrees of freedom. This implies ethnocentrism (religious pluralism and ethnicity) has significant influence on sustainable national development in Nigeria. The authors concluded that despite the religious pluralism as is observed in Nigeria, Nigerians can still live peacefully among the different ethnic nationalities and carry out sustainable national development. It was however recommended that leaders should make their followers understand that Nigeria is a country for all of us and as such every citizen has equal rights and privileged to govern or lead and every leader should give equal opportunities to every sector of the country.
\end{abstract}

(C) 2017 The Authors. This is an open access article under the terms of the Creative Commons Attribution License 4.0, which allows use, distribution and reproduction in any medium, provided the original work is properly cited.

\section{Introduction}

Nigeria is a country with a conglomeration of diverse ethnic groupings and religious diversities. These religious and cultural inclines have permeated several segments of Nigeria's national lives both in public and private spheres. The reason for this pluralism and diversities in religion and cultural affinity is linked to the division and subsequent amalgamation of the entity that became Nigeria from her colonial masters. With this amalgamation, different colonies were brought together to form Nigeria; this strange bedfellows came with their different 
religions, belief systems, cultures, languages, and institutions. It is, therefore, necessary to state that this coming together of different people with different ideological thinking, culture and religion seems to be staking the different segments of the people with different religious belief systems against the other and these situations seem not to permit sustainable national development in Nigeria.

Various authors have copied the concept of religious pluralism from Rick Rood in 1999, who defined religious pluralism as "the view that all religions are equally valid as ways to God. Religious pluralism sees all religions as legitimate and valid when viewed from within their own cultural background and tradition. The general conception is that no one religion has an exclusive claim on the truth, but all constitutes varying conceptions of the Ultimate Reality. In White, (2010) cited in Lamptey, (2010) opinion, "Pluralism is an affirmation of the validity of every religion, and the refusal to choose between them, and the rejection of world evangelism. Recent studies have shown that religious pluralism has become more visible, and religious issues have grown more pronounced world over (Jackson, Miedema, Weisse \& Willlaime, 2007; Knauth, Jozsa, Bertram-Troost \& Ipgrave, 2008; Alvarez, Veinguer, Dietz, Jozsa, \& Knauth, 2009).

The long-held religious difference that existed among Protestant and Catholic churches, Orthodox Christians, and long-established Jewish groups have combined with growing multiculturalism from immigrant populations adhering to Islam, Hinduism, Buddhism, and other faiths, as well as those adhering to none, (Banchoff, 2007; Valk, Bertram-Troost, Friederici, Béraud, 2009).

While these have been the religions of other cultures, Africans and indeed Nigerians have their own form of religious worship before the coming of Western education and religion. This religious belief system as practiced by Africans is generally referred to as Traditional African Religion (ATR). Their mode of prayers include the pouring of libation with water and other forms of alcohol, sacrifice of animals, food crops and other forest products to appease the gods and goddesses of the land among others (Eneji, Ntamu, Unwanade, Godwin, Bassey, Williams \& Joseph, 2012a; Eneji, Ntamu, Ajor, Ben, Bassey \& Williams, 2012b, Ntamu, Eneji, Edinyang \& Omang, 2013; Ntamu, Abia, Edinyang \& Eneji, 2014).

Traditional Africans believe in the ascription of certain portions of the environment as the abode of the gods where they can consult their gods or goddesses when the need arises. Just like the religion practiced and believed by adherents of other religions, the traditional Africans belief that they can ask their gods or goddesses for any favor and they are always granted such request depending on the extent to which the people are in relationship with their gods/goddess (Eneji, et al., 2012a; Eneji, et al., 2012b, Ntamu, et al., 2013; Ntamu, et al., 2014). Traditional African religion does not believe in the resurrection of the dead on the last day, but believe seriously on reincarnation of the dead through new births. Their belief system is anchored on doing the things that are right and just now and its rewards come in the future. One contrasting issue about the Traditional African Religion with Christianity is that there is no heaven or hell, they believe in the land of the dead, here they will all die and go and meet their ancestors who are already there in that land. They believe that everybody that dies goes to the land of the spirits or dead see the living from their land, but the living cannot see them, but can only reach them through incantations (Weisse, Ter Avest, Battaini-Dragoni, Ipgrave, Rudelt, Willaime, 2009).

This is so because religiosity has gained relevance in the political stratification and agenda in Western Europe, in the United States, Africa and around the world. Caution must, therefore, be taken so as not to misrepresent the ever increasing political relevance of religion with the overall growth of religiosity. In view of this, Banchoff (2007) posited the idea of secularization has a long and distinguished history in the social sciences, with many seminal thinkers arguing that religiosity was declining throughout Western societies. Key leaders in the incipient social sciences of the nineteenth and early twentieth century's Auguste Comte, Herbert Spencer, Emile Durkheim, Max Weber, Karl Marx, and Sigmund Freud had generally held that religion would gradually fade in importance and cease to be significant with the advent of industrial society (Benchoff, 2007; Ter-Avest, Jozsa, Knauth, Rosón, \& Skeie, 2009; van der Want, Bakker, ter Avest, \& Everington, 2009).

In Nigeria and indeed most African societies, there has been the problem of religious intolerance amongst the different religious sects and even within the same religious sect. These cases of religious intolerance in recent times have fuelled different ethno religious crises among the different segments of the national lives of the country. These crises in recent times have snowballed into national tragedy, leading to global embarrassment. In most cases, this religious pluralism had taken a new dimension and has added ethnic dimension to the already bedeviled tragedy, (Ntamu, et al., 2012a and 2012b; Anastopoulou, 2011).

Taking a critical look at Nigeria's sociopolitical and religious diversities, one is made to understand that Nigeria is made up of more than three hundred and fifty (350) ethnic groups, with about five major languages Yoruba, Ibo, Hausa, Efik/Ibibio, Urhobo, Quas , Kanuri etc, with more than 600 dialects and tongues. Nigeria as a country 
has basically four major types of religions, Christianity, Islam, Traditional African Religion and others. This has made room for the governing of the entity called Nigeria to be complex and difficult with consistent interference from these diverse systems and practice, (Lamptey, 2010; Ntamu, et al., 2014).

Unfortunately, the Nigerian scenario seems to perfectly work against the peaceful coexistence under which religious pluralism seeks to achieve. There is the problem of wanton killing of innocent members of different congregations between the Christians and Muslim adherents, where the former sees everybody practicing Christianity as an infidel and the later seeing the Muslim adherents as brothers and sisters since the Bible said everybody around you is a neighbor and should be treated as such. Religious violence and uproar have occurred in different parts of the country, in Jos, the case of Muslim-Christian violence took more than four hundred and twenty- six lives in 2011, in Kano, and the same was the case since 2009, 2010, 2011-2013 (Ojo, 2007; Ostien, 2009). The same was the case with the Kaduna episode of 2011 where more than four hundred Christians were reported dead by such violence on Christmas day. The case was not different in Suleija where on a Christmas day, suicide bombers believed to be Muslims attacked and bombed a Catholic church.

The Maiduguri church onslaught where churches were burnt and some casualties were recorded, (Owuamanam, Francis \& Shobiye, 2009; Oyegbile \& Abdulrafiu, 2009). The Kaduna state Muslim attack on the Catholic Church and other Protestant churches became so severe that the Christian Association of Nigeria (CAN), (an umbrella body for all Christians in Nigeria) declared that for every further church burnt, ten mosques and hundreds of Islamic adherents were going to be burnt down. Sodiq, (2009) further posited that in Michika, Adamawa state, the case is even worst where the segregation is so pronounced that there have different market days for Christians and another for Muslim, the emir of the area is a Muslim and the Christians do not accord him the needed respect even when the Christian population in the area is higher in population than the Muslim communities (Sanusi, 2003).

In Michika, the market day for Christians were on Saturday, but has since been shifted to Friday from 12 o'clock, while for Muslims, the time for their market is Sunday from $8 \mathrm{Am}$. The reason for these different market days is because they do not wish to respect Christians or Muslims days of worship. These are all because they do not tolerate each other's beliefs based on their different cultures and religion, (Uchendu, 2004; Wakili, 2009; Sulaiman, 2009; Ntamu, et al., 2013, 2014).

This is more worrisome as government is forced to spend huge financial, material and human resources of the country trying to find a lasting solution to these problems, hence distracting the government from the proper function of governance (Magbadelo, 2004; Marshall, 2009, Ntamu, et al., 2014). Most scholars have observed that the problem of Nigeria is more as a result of the amalgamation of the northern and southern protectorates and colonies forming the country now referred to as Nigeria. These formations were done in 1914 by the colonial masters without regards to the diverse ethnic, tribal, cultural and religious diversities of the constituent parts (Uchendu, 2004; Sulaiman, 2009; Omipidan, 2009a).

This trend according to Ntamu et al. (2014), Ntamu et al. (2013) has also interfered severally into Nigerian political systems and power sharing formula in the country. Where the north feels like power is their exclusive right and the south as conquered territories and paupers in the corridors of power, and any political formula leaving out the north in the equation is bound to fail. The political debate in recent times has always been that the current president, who is of the northern extraction, has openly displayed his religious and tribal bigotry, where core political appointments have been positively skewed in favor of the North to the detriment of other segments of the country. This has been welcomed by public opprobrium and has generated a lot of political debates in public sphere especially when the President (Muhammadu Buhari) openly told the world that all the appointments made and those to be made in his government are based on integrity and credibility.

Furthermore, the Christians and most people from the South Eastern part of the country felt left out of key appointments, whereas some South -South people are of the view that he is a tribal president and a religious bigot, so he is busy patronizing his Hausa, Muslim and the Fulani brethren to the exclusion of the entire southern geopolitical region. Many Nigerians fear about Buhari becoming the president has been substantiated, their initial fears of having President Buhari as the president has been confirmed, where they predicted that he is going to be a religious leader, tribal warlord and he is going to practice sectional leadership as they want to make the world believe. Looking critically at this long held belief amongst Christians, they have adduced this tribal and religious coloration to paint the president an image to satisfy their religious differences.

But it is sad to note that the second person in command is not just a Christian, but a pastor before he became the number two citizen. These and many more of these religious, ethnic, cultural and tribal intolerance has led the country into different ethnic and religious crisis and wars in the recent past, leading to loss of thousands of lives 
and properties worth billions of Naira. The situation has also forced government at different levels to spend so much on internally displaced persons' up keep, accommodation and reconstructing their infrastructures in emergency situations. This is a huge drain and distraction on the part of a government and further creating more divisions between the different ethnic and religious groups in the country, hence the reason for gross Nigerian underdevelopment. It is on the basis of these perceive acrimony and intolerance between the different facets of the country that this research is designed to investigate how religious pluralism and ethnicity can be sustainably managed to bring about sustainable national development in Nigeria.

\section{Methodology}

The methodology adopted for this study is the survey inferential research design using quantitative research method. The study populations were both Christians and Muslim lecturers from 16 universities across the country. The country was divided into 2, north and south, where 8 universities (University of Calabar, University of Benin, University of Ibadan, University of Nigeria, Nsukka, University of Lagos, Federal University of Technology, Owerri, Niger-Delta University, Yenegoa, Obafemi Awolowo University, Ile Ife (South); Ahmadu Bello University Zaria, University of Jos, University of Abuja, Federal University Wukari, Othman Dan Fodio University, Sokoto, Bayero University, Kano, Modibbo Adama University of Technology, Yola, University of Maiduguri, (North) were randomly selected from each zone. This was followed by the selection of 800 respondents from among lecturers in the Departments of Sociology, Christian Religious and Cultural Studies, Arabic and Islamic Studies, Political Science and Education. The choice of these departments is based on the topic of discourse. The stage-wise random sampling technique was used for sample selection. A total of 800 respondents were selected from where 50 respondents were selected from each university. Two research questions and two hypotheses were designed to guide the study. The instrument is a well-structured questionnaire made up of three sections, with ten questions each to address the questions. The instrument was administered by the researchers and ten research assistants across the sixteen universities. T-test analysis to analyze data generated from the instruments based on the two research questions and hypotheses; results were then presented using tables.

\section{Results and discussion}

Hypothesis one: Religious tolerance does not significantly influence sustainable national and development in Nigeria. How does religious tolerance influence national development in Nigeria? The result of data analysis to test this hypothesis is as shown on Table 1.

Table 1: Result of independent t-test analysis of the influence of Religious tolerance on sustainable national development in Nigeria

\begin{tabular}{llrrrrrr}
\hline Dependent Variable & National development & $\mathrm{N}$ & Mean & $\mathrm{SD}$ & $\mathrm{df}$ & $\mathrm{t}$-value & P-value \\
\hline Religion Intolerance & Christianity & 504 & 8.2 & 2.2 & 398 & 33.9 & $.000^{*}$ \\
& Islam & 296 & 15.9 & 2.1 & & & \\
\hline
\end{tabular}

$\mathrm{N}=800, \mathrm{P}<.05$, significant*

The result on Table 1 shows the independent t-test analysis of the influence of Religious tolerance on sustainable national development in Nigeria. The mean score for Christian staff attitude towards religious tolerance was greater than the mean score for Muslim staff religious tolerance (15.9>8.2); this produced $t$ value of 33.9 with a p-value higher than the .05 significance level with 798 degrees of freedom. This implies that religious tolerance among the different religious group has a significant influence on Nigeria's national development. In other words, the country's different religious adherents' tolerance performed better than countries with a negative attitude towards religious intolerance regarding sustainable national development. Therefore the null hypothesis which stated that religious tolerance does not significantly influence sustainable national development is rejected while the alternate which states that religious tolerance does significantly influence sustainable national development is upheld. This therefore means that religious tolerance enhances sustainable national development in Nigeria.

Hypothesis two: Ethnic tolerance (ethnocentrism/ethnic factors) does not significantly influence sustainable national development in Nigeria. How does ethnocentrism (ethnic intolerance) influence sustainable national development in Nigeria? This is addressed on the result of data analyzed as shown in Table 2.

The result on Table 2 shows the mean scores and standard deviations for the two categories of respondents. The mean score for North is slightly greater than the mean score for the South $(11.86>10.73)$; this produced $t$-value of 2.41 with a p-value higher than the .05 significance level with 798 degrees of freedom. 
Table 2: Result of independent t-test analysis of the influence of ethnocentrism (ethnic factors) on sustainable national development in Nigeria

\begin{tabular}{llrrrrrr}
\hline Dependent Variable & National development & $\mathrm{N}$ & Mean & SD & df & t & p-value \\
\hline Ethnocentrism & South (Christians) & 378 & 10.73 & 4.4 & 398 & 2.41 & $.016^{*}$ \\
& North (Muslims) & 422 & 11.86 & 4.2 & & & \\
\hline
\end{tabular}

$\mathrm{N}=800, \mathrm{P}<.05$, significant*

This implies ethnocentrism have a significant influence on sustainable national development in Nigeria. In other words, people from the North believe better in ethnocentrism than their southern counterparts and this in turn influence sustainable national development in Nigeria. Therefore the null hypothesis which stated that ethnocentrism (ethnic factors) does not significantly influence sustainable national development is rejected while the alternate which states that ethnocentrism (ethnic factors) does significantly influence sustainable national development is accepted.

The data analysis, however, revealed that religious intolerance influences the growth of sustainable national development in Nigeria. In other words, the religion that are more tolerable to other religious adherents, have a positive attitude towards others and a better living and working relationships than that religion that do not tolerate other religions. These findings is supported by Weisse, et al. (2009) who discovered that religious intolerance is practiced more by people who are fanatics and want to press home their fanatical religious bigotry, the authors further concluded that both Christianity and Islam have a sacred book from Allah and God, who both religions may call by different names, but holds that we should love our neighbors as ourselves. Supporting the postulations of Weisse, et al.,(2009), Akaeze, (2009) observed that if we do love our neighbors as ourselves, do we need to kill, maim, and destroy the properties of our neighbors? The authors further averred that the letters of the Holy Quran and the Holy Bible strongly detest anybody who kills his neighbor for whatever reason. In addition, the analysis of the response to the study by the research subjects, it was found that most of these religious bigots, who believed that Christianity and Islam is a religion for the satisfaction of human personal lives have failed in their duties to God and Allah. This is so because, it is possible for both Christians and Muslims to live harmoniously together without killing, maiming or destroying neighbor's properties and can protect each others with their lives.

The finding of this research is in line with the earlier findings of Adedeji, (2009), Bakare, et al. (2009); Adesoji, (2010); Adisa, (2011); Bartolotta, (2011) and Anastopoulou, (2011) who have found out that ethnicity, ethnocentrism and religious intolerance is a major destroying factor in any nations' development. The authors further observed in their research outcomes that world powers like the former Soviet Union, Kuwait, Iraq and many countries in the middle east are suffering from gross backwardness and underdevelopment, hunger, deprivation and underdevelopment because of the activities of religious fanatics and intolerants, this they further concluded that is responsible for religious extremism and terrorism across the world and worst in the Middle East.

The research has also confirmed the findings of Omare, (1999); Craig, (2008); Harnischfeger, (2008) and Handley, (2010) who posited in their studies that when any unit of administration or leadership operate without commensurate trust for each constituents unit or members, there is bound to be distrust and insincerity. Therefore their advise is for leaders to give their followers the trust they need in leadership in order to reduce the seeming problems associated with egocentrism and ethnocentrism. It is paramount to understand that once any leadership mistrust is observed, concerted efforts should be made to bridge such gap with intentionally directed efforts; this will build trust and confidence amongst members of such unit and forge for better and collective development which is sustainable and participatory.

Based on the findings from the research, the following recommendations were made:

1. Pluralism should not be used as a tool for destroying our country's national identity and development, but should be seen as tool for strength and unity.

2. $\quad$ Ethnicity should not fuel our national differences but serve to promote "unity in diversity."

3. Religious and political leaders who view themselves as having the exclusive preserve to power are not qualified and should not be allowed to lead a multi-pluralistic country as Nigeria

4. If Christians and Muslim can adhere to the teachings of their founders through their Sacred Texts, Nigeria will be better off for it.

5. To enhance our national development, all citizens regardless of where you come from should be given a sense of belonging so that they can adequately contribute their quota to nation building.

6. Fighting and destroying lives and properties in the name of religion or ethnicity is an ill wind that blows no one any good, so religious leaders should discourage their adherents from partaking or participating in such destructive tendencies. 
7. If we are worshiping the same creator by whatever name, we should be partners in progress not sworn enemies to destroy ourselves.

\section{Conclusion}

When there is seeming observations that some section of the country are more superior than others through the appointments of more persons to any government offices more than from other zones, there is bound to be destructive criticism, this is not healthy for any nation's sustainable development. Countries with different religious and ethnic nationalities like Nigeria should make use of the federal character commission to look at appointments and representations into all federal establishments and parastatals, boards and agencies within the country. No single zone should see itself as being superior to other zones and government should do everything within the legal framework of the system, by so doing, this will entrench equal opportunities to all facets of the country thereby convincing every member having the sense of belonging to the country and having equal rights and privileges as bona fide citizens of that country. It is however concluded that sustainable national development will continue to be a mirage unless the incessant and wanton destruction of lives and properties and discrimination and favoritism are checkmated.

\section{Limitation of the study}

During the course of this study, some limitations were encountered chiefly among which are funding to carry out this research in a more enlarge and encompassing universities across the six geopolitical zones. Another serious setback during this research was the cultural and belief barriers among the different religious set, samples would have included those in the villages and communities, but most of the women who would have formed our research subject were in "pudda", where the researchers could not access them for their response. Finally, During the fieldwork, most of these communities where the researchers would have gone to get data were at war situation because of terrorist activities, so the study area and sample were then restricted only to educated university scholars, which did not include the view of the rural farmers and other facets of the society.

\section{Direction for future research}

Further researches should be carried out to cover the entire country, most especially in the rural areas on the same topic. This will give a broader coverage. Another study should also be carried out with variables such as demographic variables like gender, income level, occupation, educational level and other such variables to assess how these variables influence ethno-religious pluralism and sustainable national development in Nigeria.

\section{References}

Adedeji, Ademola (2009), 1000 Boko Haram Members in Prison, Awaiting Trial - Mustapha, In: The Punch (Lagos), 14 October, 14.

Adesoji, Abimbola (2010), The Boko Haram Uprising and Islamic Revivalism in Nigeria, In: Africa Spectrum, 45(2), 95-108.

Adisa, A. I. (2011). Boko Haram: Security Implication in Nigeria: A Paper Presented in Lagos At a Village Square Meeting on Security in Nigeria, Unpublished.

Akaeze, A. (2009). From Maitatsine To Boko Haram, Newswatch (Lagos), 28 October, Online: $<$ Http://Www.Newswatchngr.Com/Index.Php?Option

Alvarez Veinguer, A., Dietz, G., Jozsa, D.-P., Knauth, T. (Eds.) (2009), Islam in Education in European countries Pedagogical Concepts and Empirical Findings, Münster: Waxmann.

Anastopoulou, L., (2011). Pluralism and religious diversity, social cohesion and integration in Europe. Insights from European research. Directorate-General for Research and Innovation, Directorate B - European Research Area Unit B.5 - Social Sciences and Humanities

Bakare, W., Ademola, A. \& Hammed, S. (2009). Islamic Militant Leader Killed - Borno Government, In: The Punch (Lagos), 31 July, 5.

Banchoff, T. (2007). Democracy and the New Religious Pluralism. New York, Oxford University Press, Inc.

Bartolotta, C. (2011). "Terrorism in Nigeria: The Rise of Boko Haram". The Whitehead Journal of Diplomacy and International Relations.

Craig, W. (2008). "Is Uncertainty a Sound Foundation for Religious Tolerance?" in Religious Tolerance through Epistemic Humility: Thinking with Philip Quinn, J. Kraft and D. Basinger, (eds.), Burlington, VT: Ashgate Publishing Company.

Eneji C.V.O, Ntamu G.U, Ajor J.O, Ben C.B, Bassey John E \& Williams, J.J. (2012). Ethical Basis of African Traditional Religion and Socio-cultural Practices in Natural Resources Conservation and Management in Cross River State, Nigeria, Journal of Research in Peace, Gender and Development, 2(2), 034-043, 
Eneji, C.V.O, Ntamu, G.U, Unwanade, C.C, Godwin, A.B., Bassey J.E., Williams, J.J \& Joseph, I.G. (2012). Traditional African Religion in Natural Resources Conservation and Management in Cross River State, Nigeria. Environment and Natural Resources Research, 2(4), 45-53

Handley, M. (2010). The Violence in Nigeria: What's Behind the Conflict? Time World, Wednesday, Mar. 10, 2010

Harnischfeger, J. (2008). Democratization and Islamic Law: The Sharia Conflict in Nigeria, Frankfurt/New York, Campus Verlag, 244

Jackson, R., Miedema, S., Weisse, W., Willlaime, J.-P. (Eds.) (2007) Religion and Education in Europe: Developments, Contexts and Debates, Münster: Waxmann.

Knauth, T., Jozsa, D.-P., Bertram-Troost, G., Ipgrave, J. (Eds.) (2008), Encountering Religious Pluralism in School and Society - A Qualitative Study of Teenage Perspectives in Europe, Münster: Waxmann.

Lamptey, J. (2010). "Embracing Relationality and Theological Tensions: Muslim Theology, Religious Diversity, and Fate," presented at the International Symposium on Islam, Salvation, and the Fate of Others (University of Illinois, April 15-17, 2010) and forthcoming in a published collection of symposium presentations.

Magbadelo, J. O. (2004). Pentecostalism in Nigeria: Exploiting or edifying the masses? African Sociological Review, 8(2), 15-29.

Marshall, R. (2009). Political spiritualists: The Pentecostal revolution in Nigeria. Chicago, IL: University of Chicago Press. http://dx.doi.org/10.7208/chicago/9780226507149.001.0001

Ntamu, G.U., Abia, O.T., Edinyang, S.D. \& Eneji, C.V.O. (2014). Religion in Nigerian Political Space: Implication for Sustainable National Development. International Journal of Academic Research in Business and Social Sciences, 4 (9), 301-318

Ntamu, G.U., Eneji, C.V.O, Edinyang, S.D, and Omang T.A (2013) Religion! A curse or Blessing for National Integration and Development in Nigeria: Boko Haram in Perspective, Journal of Sociological Research, Vol. 4 (1), 364-377

Ojo, M. (2007). Pentecostal movements, Islam and the contest for public space in Northern Nigeria, Islam and Christian-Muslim Relations, 18(2), 172-188. http://dx.doi.org/10.1080/09596410701214043

Omare, O. (1999). Enhancing Democracy In Nigeria Through Social Studies Education. Nigeria Journal of Social Studies Review8(1), 33-39.

Omipidan, I. (2009b). Revealed! How Yusuf's Father Began Boko Haram Ideology in the 1960s, In: Saturday Sun (Lagos), 26 September, 48.

Omipidan, I. (2009a). Why North Is On Fire, In: Sunday Sun (Lagos), 2 August, 5-6.

Ostien, P. (2009). Jonah Jang and the Jasawa: Ethno-religious Conflict in Jos, Nigeria. Muslim Christian Relations in Africa.

Owuamanam, J., Francis, F. \& Shobiye, H. (2009). The Rise, Threat and Fall of Boko Haram, In: Saturday Punch (Lagos), 1 August, 2-3.

Oyegbile, O., \& Abdulrafiu, L. (2009). Shielding Patrons of Boko Haram, In: Tell (Lagos), 17 August, 67-71. Platform. Retrieved 12 June 2011 from http://www.archivalplatform.org/blog/entry/folklorising/

Rick rood, V. (1999). Do All Roads Lead to God? The Christian Attitude Toward Non-Christian Religions. ProbesAlert Newsletter, 30 th August, 1999.

Sanusi, L. S. (July 2003). The Sharia debate and the construction of a 'Muslim' identity in Northern Nigeria: A critical perspective. Paper delivered at a seminar on The Sharia debate and the construction of Muslim and Christian identities in Northern Nigeria University of Bayreuth, Germany.

Sodiq, Y. (2009). Can Muslims and Christians live together peacefully in Nigeria? The Muslim World, 99, 646688. http://dx.doi.org/10.1111/j.1478-1913.2009.01292.x

Sulaiman, T. (2009). The Plot to Islamize Nigeria, In: Tell (Lagos), 30 November, 19-23.

Ter Avest, I., Jozsa, D.-P., Knauth, T., Rosón, J., Skeie, G. (Eds.) (2009), Dialogue and Conflict on Religion. Studies of Classroom Interaction in European Countries, Münster: Waxmann.

Uchendu, E. (2004), Religion and Nation-Building in Nigeria, In: Nigeria Heritage, 13, 132-144.

Valk, P., Bertram-Troost, G., Friederici, M., Béraud, C. (Eds.) (2009), Teenagers' perspectives on the Role of Religion in their Lives, Schools and Societies. A European Quantitative Study, Münster: Waxmann.

van der Want, A., Bakker, C., ter Avest, I., Everington, J. (Eds.) (2009), Teachers Responding to Religious Diversity in Europe, Münster: Waxmann. b) internet publications: Weisse, W., Jackson, R., Rudelt, C., Willaime, J.P. (Eds.) (2009) Religion in Education - a Con-tribution to Dialogue or a Factor of Conflict? The REDCo-project: Presentation in the European Parliament, Brussels, December 2008.

Wakili, H. (2009). Islam and the political arena in Nigeria: The Ulama and the 2007 elections. Institute for the Study of Islamic Thought in Africa (ISITA): Northwestern University.

Weisse, W., ter Avest, I., Battaini-Dragoni, G., Ipgrave, J., Rudelt, C., Willaime, J-P. (Ed) (2009), The relevance of interreligious dialogue for intercultural understanding. The White Paper 'Living together as Equals in Dignity' of the Council of Europe and the principal findings of the European research project REDCo. Documentation of a public event in the Council of Europe, Strasbourg, March 2009. 